\title{
Scaling of wood pallet fires
}

\author{
Ying Zhen Li, Haukur Ingason
}
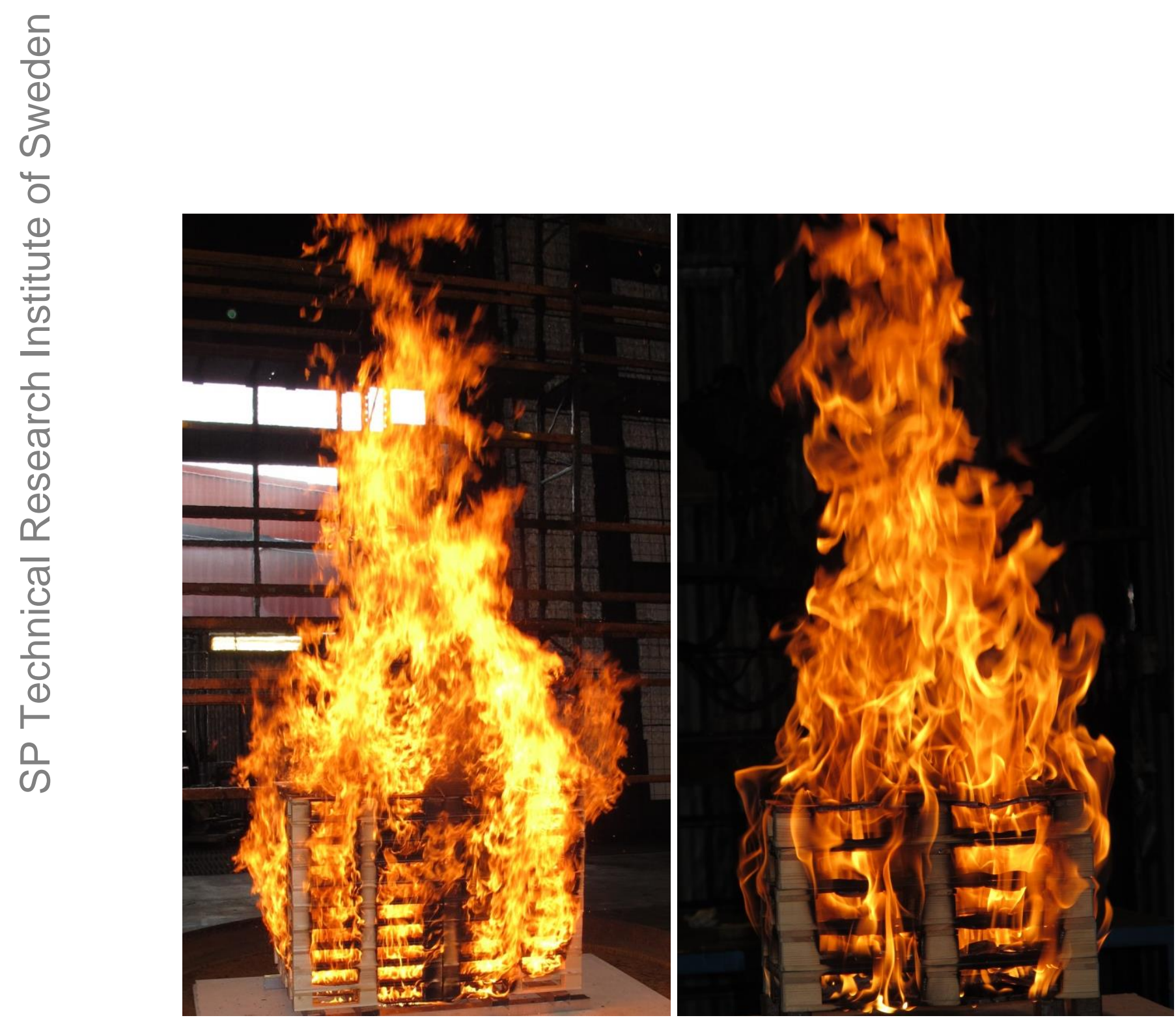

Fire Research 


\section{Scaling of wood pallet fires}

Ying Zhen Li, Haukur Ingason 


\section{Abstract}

\section{Scaling of wood pallet fires}

A method for scaling time-resolved burning behaviours of wood pallet fires has been developed. A series of validation tests was carried out in two different scales and the time-resolved heat release rates were obtained and compared. The results show that the scaling method proposed works very well. In reality, the scaling method proposed can be applied as a general scaling method for pallets and other similar types of fuels, e.g. more general wood pallets and plastic pallets. The method provides a high potential for use of scaling for fire sources.

Key words: scaling, fire, wood pallet, burning behavior, heat release rate

SP Sveriges Tekniska Forskningsinstitut

SP Technical Research Institute of Sweden

SP Report 2014:57

ISBN 978-91-88001-01-6

ISSN 0284-5172

Borås 2014 


\section{Contents}

Abstract $\quad 3$

Contents $\quad 4$

Preface 5

Summary 6

$\begin{array}{ll}\text { Nomenclature } & 7\end{array}$

1 Introduction $\quad 8$

$2 \quad$ Froude scaling $\quad 10$

$3 \quad$ Scaling of wood pallet fires $\quad 11$

3.1 Geometric parameters for a wood pallet pile 11

$\begin{array}{ll}3.2 & \text { Scaling of wood pallet fires } \\ \end{array}$

4 Validation tests 16

$5 \quad$ Results and discussion $\quad 18$

5.1 Comparison of test results 18

5.2 Maximum heat release rates 19

6 Summary 21

$\begin{array}{lll}7 & \text { References } & 22\end{array}$ 


\section{Preface}

This project was sponsored by the Swedish Fire Research Board (BRANDFORSK) and SP Tunnel and Underground Safety Centre which are greatly acknowledged.

Glenn Appel and the technicians Sven-Gunnar Gustafsson, Tarmo Karjalainen and Michael Magnusson at SP Fire Research are acknowledged for the construction of the test rig and the valuable assistance during performance of the tests.

The advisory group to the project is thanked for their contribution. The advisory group consisted of:

Anders Palm, SSBF

Sören Lundström, MSB

Pia Ljunggren, Trygg Hansa

Hans Nyman, Brandskyddslaget

Jonas Andersson, Stockholms Stad

Kristian Becker, Brandskyddslaget

Magnus Arvidson, SP

Ulf Lundström, Trafikverket 


\section{Summary}

A method for scaling time-resolved burning behaviours of wood pallet fires has been developed.

The scaling method proposed shows that both the geometrical parameters for a single pallet and the number of pallets in each direction scale as $1 / 2$ power of the length scale. A summary of the scaling correlations is provided.

In order to validate the scaling method, a series of validation tests was carried out in two different scales and the time-resolved heat release rates were obtained and compared. The results show that the scaling method proposed works very well.

Test data for the maximum heat release rates obtained from tests in different scales were compared. The scaled-up heat release rates per wood pallet (full scale) are all in a range of $176 \mathrm{~kW}$ to $192 \mathrm{~kW}$. This strongly supports the assumption on the mass burning rate for wood pallets and also indicates that the full scale maximum heat release rate should scale well.

In reality, the scaling method proposed can be used as a general scaling method for pallet fires. Its use does not limit to a specific wood pallet. Instead, it can be applied to other similar types of fuels, e.g. more general wood or plastic pallets, rather than only European wood pallets. The advantage of such a scaling is that individual parts can be scaled easily without any changes in details. 


\section{Nomenclature}

\begin{tabular}{|c|c|c|}
\hline$a$ & geometrical parameter for pallet (m) & Greek symbols \\
\hline$A_{f}$ & total fuel surface area $\left(\mathrm{m}^{2}\right)$ & $\rho_{f} \quad$ fuel density $\left(\mathrm{kg} / \mathrm{m}^{3}\right)$ \\
\hline$A_{f, e x}$ & total exposed fuel surface area $\left(\mathrm{m}^{2}\right)$ & \\
\hline$A_{f, \text { cont }}$ & total contact area in a pile $\left(\mathrm{m}^{2}\right)$ & Sup and Subscripts \\
\hline$A_{f o, c o n t}$ & $\begin{array}{l}\text { contact area for one pallet inside a pile } \\
\left(\mathrm{m}^{2}\right)\end{array}$ & fuel \\
\hline$b$ & geometrical parameter for a pallet (m) & single pallet \\
\hline$c$ & geometrical parameter for a pallet (m) & full scale \\
\hline$d$ & geometrical parameter for a pallet $(\mathrm{m})$ & symbol for $\mathrm{x}, \mathrm{y}, \mathrm{z}$ \\
\hline E & energy $(\mathrm{kJ})$ & model scale \\
\hline$f$ & parameter in Table $2(\mathrm{~m})$ & $\mathrm{x}$ axis (longitudinal) \\
\hline$l$ & length of a pallet in one direction $(\mathrm{m})$ & y axis (transverse) \\
\hline$L$ & length scale (m) & $\mathrm{z}$ axis (vertical) \\
\hline$L_{x}$ & total length of a pile in $\mathrm{x}$ direction $(\mathrm{m})$ & scaling coefficient \\
\hline$L_{y}$ & total length of a pile in y direction (m) & \\
\hline$L_{z}$ & total length of a pile in $\mathrm{z}$ direction $(\mathrm{m})$ & \\
\hline$m$ & mass $(\mathrm{kg})$ & \\
\hline$\dot{m}_{f}^{\prime \prime}$ & mass burning rate $\left(\mathrm{kg} /\left(\mathrm{m}^{2} \mathrm{~s}\right)\right)$ & \\
\hline$N$ & number of pallet layers in a direction & \\
\hline$\dot{Q}$ & heat release rate $(\mathrm{HRR})(\mathrm{kW})$ & \\
\hline$s$ & spacing parameter in a wood pallet $(\mathrm{m})$ & \\
\hline$t$ & time $(\mathrm{s})$ & \\
\hline$T$ & temperature $(\mathrm{K})$ & \\
\hline$u$ & velocity $(\mathrm{m} / \mathrm{s})$ & \\
\hline$V_{f}$ & fuel volume $\left(\mathrm{m}^{3}\right)$ & \\
\hline$V_{f o}$ & fuel volume of a single pallet $\left(\mathrm{m}^{3}\right)$ & \\
\hline$\dot{V}$ & fuel volume of a single pallet $\left(\mathrm{m}^{3}\right)$ & \\
\hline$w_{p}$ & $\begin{array}{l}\text { total wet perimeter of the fuel in one } \\
\text { direction }(\mathrm{m})\end{array}$ & \\
\hline
\end{tabular}




\section{Introduction}

The physical scaling has been widely used in fire safety science community. Its application permeates nearly every aspect of fire research, from free plumes to fire suppression. Despite the simplification in various applications, the scaling technique has significantly improved our understanding of fire dynamics. Heskestad [1] reviewed scaling techniques, mainly pressure modeling and Froude modeling. These are the two main techniques that have been used. Quintiere [2] also reviewed the scaling applications in fire research with a focus on ceiling jets, burning rate, flame spread and enclosure fires. Ingason [3] carried out numerous studies on fire development in rack-storage fires, both in large scale and model scale. The in-rack conditions were found to scale very well. Perricone et al. [4] investigated the thermal response of a steel tube covered by insulating materials using scaling principles. However, the scaling laws used for the thick insulating materials may not be accurate. Li and Hertzberg [5] conducted a scaling study of heat conduction and heat balance in a room fire. They carried out two series of room fire tests in three different scales where the aim was to investigate the scaling of temperatures inside the walls. A good agreement between different scales was found.

Scaling of water-based fire suppression systems has also been conducted in open and enclosure fires. Heskestad [6,7] carried out a series of gas and pool fire suppression tests to investigate the credibility of scaling the interaction of water sprays and flames, and obtained a simple correlation for extinguishment of gas and pool fires using water sprays. Quintiere et al's work [8] showed that the scaling of suppression of pool and gas fires worked well, although the results in rack-storage fires between model and full scale did not show a good correlation. Yu et al. $[9,10]$ tested and investigated the scaling of suppression of gas fires and pool fires using water mist systems and obtained good agreement between model scale and full scale.

In the field of tunnel fire safety, scaling techniques are widely used. The main reason promoting their applications is the high cost of full scale tunnel tests. Note that even in model scales, the ratio of tunnel length to tunnel height should be great enough to scale a realistic tunnel fire. Fortunately the introduction of longitudinal flows allows us to slightly reduce the scaling ratio, compared to an enclosure fire.

A large number of model scale tunnel fire tests have been carried out in the past two decades. Bettis et al. [11] carried out nine fire tests using scale models of vehicles in a model tunnel to mimic part of a train used to transport HGVs through the Channel tunnel. Oka and Atkinson [12] carried out a study of critical velocity in a model tunnel. Further, $\mathrm{Wu}$ and Bakar [13] carried out tests to investigate the influence of tunnel geometry on the critical velocity. Ingason and Li investigated the key parameters for large fires in model scale tunnels with longitudinal ventilation [14] and with point extraction ventilation [15]. Ingason [16] also carried out a series of 1:10 scale model railcar tunnel fire tests to investigate the effect of openings on the fire sizes. Vauquelin et al. [17] carried out a series of model scale experiments with a helium/nitrogen gas mixture in an isothermal test-rig to investigate the extraction capability and efficiency of a two-point extraction system. Li and Ingason [15] pointed out that the cold gas method used by Vauquelin et al. [17] results in experimental inaccuracy, and therefore is not recommended to use in tunnel fire tests.

Li et al. [18-22] carried out several series of model scale tunnel fire tests to investigate the critical velocity [18], backlayering length [18], maximum ceiling gas temperature [19, 20], smoke control in cross-passages [21], and smoke control in rescue stations in long railway tunnels [22]. Lönnermark et al. [23] carried out a 1:3 model scale metro car fire tests in preparation for the full scale fire tests in the Brunsberg tunnel [24]. Model scale 
tunnel fire tests with water-based fire suppression have also been carried out. Ingason [25] tested the water spray system in tunnel fires using hollow cone nozzles and wood crib fires. Deluge system and water curtain system were tested. Li and Ingason [26] investigated the automatic water spray system in tunnel fires using full cone nozzles and wood crib fires. Response times for individual sprinklers were modeled using a scaling theory. Li and Ingason [27] also carried out a series of model scale tunnel fire tests with fire suppression systems using wood pallets as fuels.

Despite the wide use and experience of the physical scaling, scaling of general solid fuels has not been possible, with the exception of the wood crib fires. The reason for its exception is that much work had been carried out on burning rates of wood cribs in 1960s and 1970s when the wood cribs started to become a commonly used solid fire source in experiments [28-30]. A wood crib is a pile of small bricks stacked together with uniform spacing between them. For each wood crib, there are only four geometrical parameters: stick size (rectangular), spacing between sticks, number of layer in the horizontal direction and number of layer in the vertical direction. Research on the burning rates of these small wood cribs provides valuable inputs and facilitated the scaling of wood cribs. Cross [31, 32] examined the scaling of wood crib fires and found good agreement between different scales.

Wood pallets are widely used in, e.g., storage and transportation. Wood pallets have also been one standard fuel in representation of cellulose fuels in many large scale fire tests, e.g. tunnel fire tests [33-35] and rack storage fire tests [36]. These types of large scale tests mostly involve in tons of fuels and the cost of each test is huge. Sometimes the problem with measurement of the heat release rates using an industrial calorimeter in the lab could even emerge.

A general method to scale wood pallets is therefore needed. This would make it possible in future to do large scale tests in tunnels or industrial buildings more cost effectively, without jeopardizing the accuracy of the results to any large extend. This applies especially for scaling of fires without interaction of suppression systems. The motivation for doing this type of research is therefore both economical and scientific. The potential for future use of scaling technique for this type of fuel in different applications is therefore extensive.

In the following a general method for scaling of wood pallet fires is proposed and validation tests are carried out. The results are analysed based on a theory developed especially for this type of fuel: wood pallets. 


\section{$2 \quad$ Froude scaling}

The widely used and well known Froude scaling technique is applied as the basis for the scaling of wood pallets. It is impossible and in most cases not necessary to preserve all the terms obtained by scaling theory simultaneously, the terms that are most important and most related to the study are preserved. The fire induced turbulence and radiation are implicitly scaled. The Froude scaling has been used widely in open and enclosure fires and results from model scale tests seem to fit full scale results well, see e.g. Li and Hertzberg's work [5]. Research on tunnel fires also shows there is a good agreement between model scale and full scale test results on many focused issues [14, 15, 18-20, 3739].

A complete scaling theory can be found in the book [40]. Scaling correlations for some key variables such as heat release rate, gas temperature and velocity is shown in Table 1.

Table 1 A list of scaling correlations for the model.

\begin{tabular}{|l|l|c|}
\hline \multicolumn{1}{|c|}{ Type of unit } & Scaling model $^{*}$ & Eq. number \\
\hline $\begin{array}{l}\text { Heat Release Rate (HRR) } \\
\text { Volume flow }\left(\mathrm{m}^{3} / \mathrm{s}\right)\end{array}$ & $\frac{\dot{Q}_{F}}{\dot{Q}_{M}}=\left(\frac{L_{F}}{L_{M}}\right)^{5 / 2}$ & Eq. (1) \\
\hline Velocity (m/s) & $\frac{\dot{V}_{F}}{\dot{V}_{M}}=\left(\frac{L_{F}}{L_{M}}\right)^{5 / 2}$ & Eq. (2) \\
\hline Time (s) & $\frac{u_{F}}{u_{M}}=\left(\frac{u_{F}}{u_{M}}\right)^{1 / 2}$ & Eq. (3) \\
\hline Energy (kJ) & $\frac{t_{F}}{t_{M}}=\left(\frac{L_{F}}{L_{M}}\right)^{1 / 2}$ & Eq. (4) \\
\hline Mass (kg) & $\frac{E_{F}}{E_{M}}=\left(\frac{L_{F}}{L_{M}}\right)^{3}$ & Eq. (5) \\
\hline Temperature (K) & $\frac{m_{F}}{m_{M}}=\left(\frac{L_{F}}{L_{M}}\right)^{3}$ & Eq. (6) \\
\hline
\end{tabular}

*Assume the ratio of effective heat of combustion $\Delta H_{c, M} / \Delta H_{c, F}=1 . L$ is the length scale.

Index $M$ refers to model scale and index $F$ to full scale. 


\section{$3 \quad$ Scaling of wood pallet fires}

In the following, the general scaling method for pallet fires is proposed with a focus on the standard European wood pallet fires. The scaling method proposed and the results obtained, however, does not limit to a specific wood pallet. Instead, it can be applied to other similar types of fires.

\subsection{Geometric parameters for a wood pallet pile}

A standard European pallet (EUR pallet) consists of three layers of wood slabs and 9 wood blocks in the vertical direction, see Figure 1. The wood slabs consist of two longitudinal slab layers and one horizontal slab layer. The thickness of one full-scale wood pallet is $144 \mathrm{~mm}$. The geometrical parameters for a single wood pallet, i.e. $a, b, c$, $d, s_{x}, s_{y}, l_{x}, l_{y}$ and $l_{z}$ are defined as shown in Figure 1.

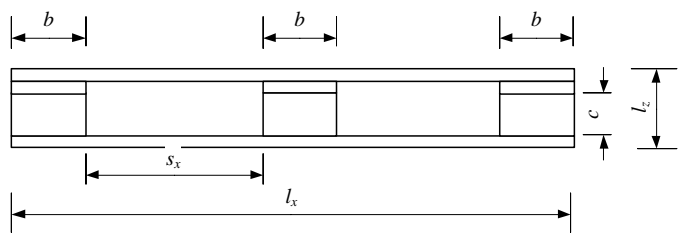

(a) Front view (longer side)

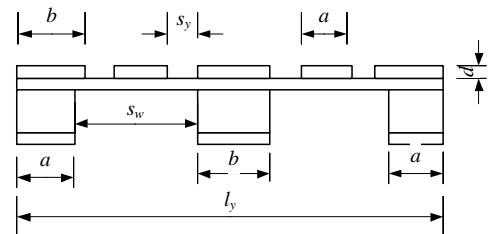

(b) Side view (shorter side)

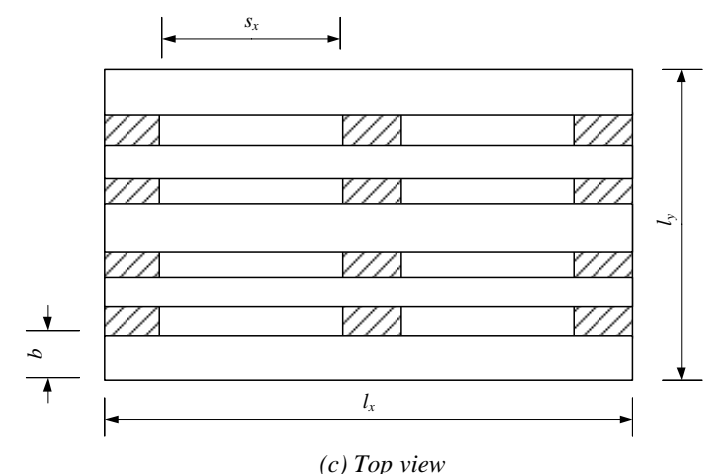

Figure 1 Geometry of a standard European wood pallet.

For a wood pallet pile, more parameters need to be defined, including the number of wood pallets in the $x$ axis, the number of wood pallets in the y axis, $N_{y}$, and the number of wood pallets in the vertical direction, $N_{z}$, see Figure 2. The total length is defined as $L_{x}$, $L_{y}$, and $L_{z}$ in the corresponding direction. In this drawing, $N_{x}=2, N_{y}=2$ and $N_{z}=8$. 

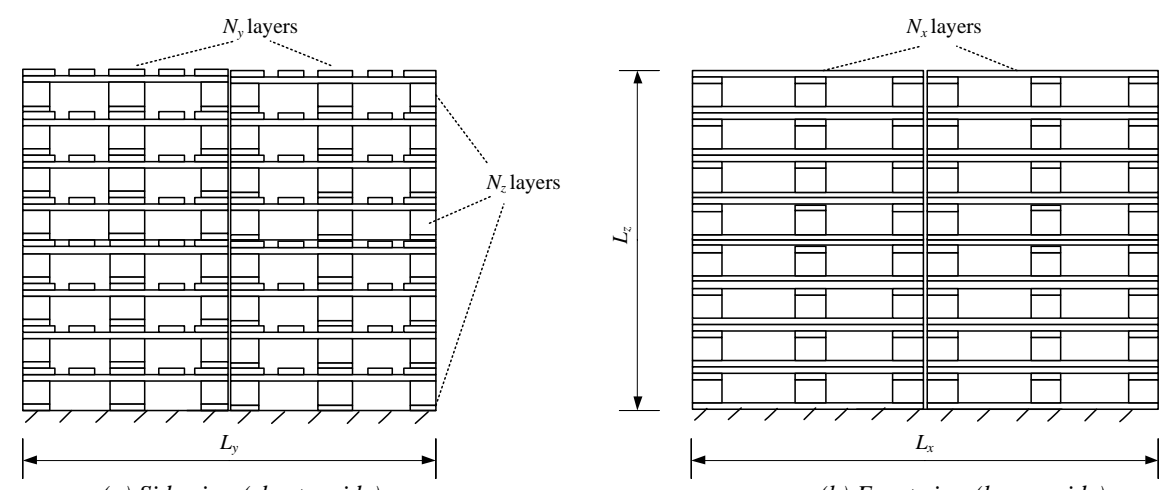

(a) Side view (shorter side)

(b) Front view (longer side)

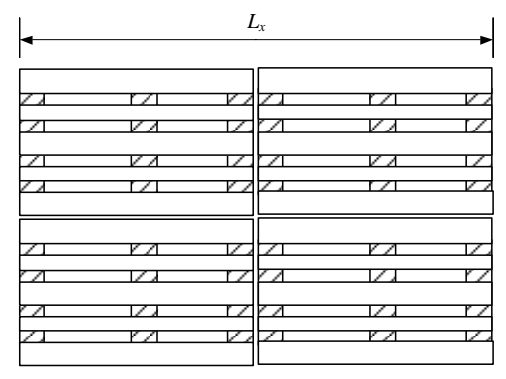

(c) Top view

Figure 2 Geometry of a wood pallet pile.

\subsection{Scaling of wood pallet fires}

To scale the combustible materials, three basic parameters need to be accounted for: geometry, heat release rate and energy content. The coverage of the fuels needs to be scaled geometrically, which indicates:

$$
L_{x} \propto L^{1}, \quad L_{y} \propto L^{1}, \quad L_{z} \propto L^{1}
$$

where $L$ is length scale, $L_{x}, L_{y}$ and $L_{z}$ are the total length of a pallet pile in the longitudinal (length), transverse (width) and vertical (height) directions respectively.

The total length in the longitudinal direction, $L_{x}$, can be expressed as:

$$
L_{x}=N_{x} l_{x}
$$

where

$$
l_{x}=2 s_{x}+3 b
$$

The total length in the transverse direction, $L_{y}$, can be expressed as:

$$
L_{y}=N_{y} l_{y}
$$

where

$$
l_{y}=2 a+3 b+4 s_{y}
$$

The total length in the vertical direction, $L_{z}$, can be expressed as:

$$
L_{z}=N_{z} l_{z}
$$

where 


$$
l_{z}=a+2 d=c+3 d
$$

It is assumed that for each small piece of wood (e.g. a slab) inside a wood pallet pile, the burning approximates to a quasi-steady state (or the transition time to a quasi-steady state is very short) and therefore the burning rate approximates a constant. Ingason and $\mathrm{Li} \mathrm{[14,}$ 15] found out that the maximum mass burning rate for wood cribs approaches constant for well ventilated fires, which supports this assumption.

The heat release rate, or the mass burning rate for the same type of fuels (wood in this work) in both scales need to be scaled as:

$$
\dot{m}_{f}^{\prime \prime} A_{f, e x} \propto L^{5 / 2}
$$

The exposed fuel surface area for a wood pallet pile can approximately be expressed as:

$$
A_{f, e x}=A_{f}-A_{f, \text { cont }}=N_{x} N_{y} N_{z} A_{f o}
$$

The exposed surface area for a single wood pallet, $A_{f o}$, is:

$$
A_{f o}=8 l_{x} b+8 l_{x} a+6 l_{y} b+2 d\left(4 a+7 b+8 l_{x}+3 l_{y}\right)+12 a c+24 b c-24 a b-24 b^{2}
$$

The total contact area between wood pallets in a wood pallet pile, $A_{f, c o n t}$, can approximately be expressed as:

$$
A_{f, \text { cont }} \approx N_{x} N_{y} N_{z} A_{f o, c o n t}
$$

where the contact area for a single wood pallet placed inside the pile is

$$
A_{f o, \text { cont }}=2 l_{x}(2 a+b+2 d)+2 l_{y} d+4 a d+6 b d+4 a^{2}+8 a b
$$

The energy content, or the fuel mass for the same type of fuels in both scales, need to be scaled as:

$$
E \propto m_{f}=\rho_{f} V_{f}=\rho_{f} N_{x} N_{y} N_{z} V_{f o} \propto L^{3}
$$

where

$$
V_{f o}=4 l_{x} d(a+b)+3 l_{y} b d+6 a b c+3 b^{2} c
$$

A dimensional analysis of the above correlations, i.e. Eq. (8) to Eq. (16), indicates:

$$
\begin{gathered}
L_{x}^{*}=N_{x}^{*}+l_{x}^{*}=1 \\
l_{x}^{*}=s_{x}^{*}=b^{*} \\
L_{y}^{*}=N_{y}^{*}+l_{y}^{*}=1 \\
l_{y}^{*}=a^{*}=b^{*}=s_{y}^{*} \\
L_{z}^{*}=N_{z}^{*}+l_{z}^{*}=1 \\
l_{z}^{*}=a^{*}=d^{*}
\end{gathered}
$$




$$
\begin{gathered}
N_{x}^{*}+N_{y}^{*}+N_{z}^{*}+A_{f o}^{*}=\frac{5}{2} \\
A_{f o}^{*}=l_{x}^{*}+a^{*}=l_{y}^{*}+b^{*}=a^{*}+d^{*}=a^{*}+c^{*}=b^{*}+c^{*} \\
N_{x}^{*}+N_{y}^{*}+N_{z}^{*}+V_{f o}^{*}=3 \\
V_{f o}^{*}=l_{x}^{*}+d^{*}+a^{*}=l_{x}^{*}+d^{*}+b^{*}=l_{y}^{*}+b^{*}+d^{*}=a^{*}+b^{*}+c^{*}=2 b^{*}+c^{*}
\end{gathered}
$$

where the superscript "*” indicates the scaling coefficient of the length scale. For example, $N_{x} \propto L^{N_{x}^{*}}$ indicates that the parameter $N_{x}$ scales as $N_{x}^{*}$ power of length scale $L$.

By solving the above equations, we obtain the scaling laws for the geometrical parameters:

$$
\begin{gathered}
a^{*}=b^{*}=d^{*}=s_{x}^{*}=s_{y}^{*}=l_{x}^{*}=l_{y}^{*}=l_{z}^{*}=\frac{1}{2} \\
N_{x}^{*}=N_{y}^{*}=N_{z}^{*}=\frac{1}{2} \\
L_{x}^{*}=L_{y}^{*}=L_{z}^{*}=1
\end{gathered}
$$

This indicates that both the geometrical parameters for a single pallet and the number of pallets in each direction scale as $1 / 2$ power of the length scale. Note that the total side length in each direction scales as the length scale. A summary of the scaling correlations is given in Table 2 .

Scaling of the mass burning rate and energy content can be easily checked, which scales as $5 / 2$ and $3^{\text {rd }}$ power of the length scale respectively. Given that the vent factors in enclosure fires or the mass flow rates under wind or in case of tunnel fires also scale as $5 / 2$ power of the length scale, as the heat release rates of the wood pallets do, the scaling method proposed here can be applied to enclosure fires or tunnel fires.

In most cases, the transient heat release rate curves are of interest. Li and Ingason [37] showed that the fire growth rate for solid fuels exposed to wind is proportional to the wet perimeter of the fuel. The scenarios are similar to fires with mainly vertical fire spread, as the hot gases flowing through the surfaces are also forced air flow. According to Li and Ingason's work [37], to preserve the fire growth rate the total wet perimeter should scale as $3 / 2$ power of the length scale. Note that the total average wet perimeter in one direction (either of the three directions), $w_{p}$, can approximately be expressed as:

$$
w_{p}=\frac{A_{f}}{L}=\frac{N_{x} N_{y} N_{z} A_{f o}}{L}
$$

The average wet perimeter apparently scale as $3 / 2$ power of the length scale, which indicates that the fire growth rate can be scaled well. In other words, the transient heat release rate curves can be well reproduced in model scales.

In reality, the scaling theory proposed above can also be applied to other types of fuels, e.g. more general wood pallets or plastic pallets, rather than only European wood pallets. The advantage of such a scaling is that individual parts can be scaled easily without any 
changes in details and the main controlling parameter is the number of the individual pallets or parts.

Table 2 Summary of scaling correlations for wood pallet fires.

\begin{tabular}{|l|l|c|}
\hline Parameter $(\mathrm{m})$ & Scaling model & Eq. number \\
\hline$f(a, b, c$ and $d)$ & $f_{M} / f_{F}=\left(L_{M} / L_{F}\right)^{1 / 2}$ & Eq. (31) \\
\hline$s_{i}(i=x, y)$ & $s_{i, M} / s_{i, F}=\left(L_{M} / L_{F}\right)^{1 / 2}$ & Eq. (32) \\
\hline$l_{i}(i=x, y, z)$ & $l_{i, M} / l_{i, F}=\left(L_{M} / L_{F}\right)^{1 / 2}$ & Eq. (33) \\
\hline$N_{i}(i=x, y, z)$ & $N_{i, M} / N_{i, F}=\left(L_{M} / L_{F}\right)^{1 / 2}$ & Eq. (34) \\
\hline$L_{i}(i=x, y, z)$ & $L_{i, M} / L_{i, F}=\left(L_{M} / L_{F}\right)^{1}$ & Eq. (35) \\
\hline
\end{tabular}




\section{$4 \quad$ Validation tests}

Lab tests were carried out in two different scales to validate the scaling of wood pallet fires. The scaling ratio applied in the validation tests is $1: 4$. To reduce the fire size tested in the lab, fuels consisting of 1/2 wood pallets (1:2 scale wood pallets) are used as full scale (but here we call it "intermediate scale" to avoid confusion). Therefore $1 / 4$ wood pallets are used in model scale, according to the scaling correlations proposed, see Table 2. The geometrical parameters of the wood pallets of different sizes can be found in Table 3.

Table 3 Geometrical parameters for the European wood pallets of different sizes (Dimensions in $\mathrm{mm}$ ).

\begin{tabular}{|c|c|c|c|}
\hline Parameters & $1 / 1$ wood pallet & $1 / 2$ wood pallet & $1 / 4$ wood pallet \\
\hline$l_{x}$ & 1200 & 600 & 300 \\
\hline$L_{y}$ & 800 & 400 & 200 \\
\hline$L_{z}$ & 144 & 72 & 36 \\
\hline$a$ & 100 & 50 & 25 \\
\hline$b$ & 145 & 72.5 & 36.25 \\
\hline$c$ & 78 & 39 & 19.5 \\
\hline$d$ & 22 & 11 & 5.5 \\
\hline$s_{x}$ & 382.5 & 191.3 & 95.6 \\
\hline$s_{y}$ & 40 & 20 & 10 \\
\hline$s_{w}$ & 227.5 & 113.8 & 62.9 \\
\hline
\end{tabular}

A summary of the validation tests is presented in Table 4 . Two series of tests were carried out. The number of pallets in each direction is scaled as $1 / 2$ power of the length scale. In model scales, only one pile of wood pallets was tested $\left(N_{x}=1\right.$ and $\left.N_{y}=1\right)$. Two photos are presented in Figure 3 from which it can be found that the flame shapes including flame heights are of high similarity.

The pallet piles were placed on weighing platforms to measure the fuel mass loss rate. The fuels were slightly raised and small pools were placed right at the bottom of the fuels as ignition sources. The humidity of the wood pallets tested was approximately $10 \%$.

The ignition source for the intermediate scale tests, i.e. test 3 and test 4 , was a $0.25 \mathrm{~m} \times$ $0.25 \mathrm{~m}$ pool filling with $0.4 \mathrm{~L}$ heptane. In model scale tests, i.e. test 1 and test 2 , the ignition source was a $0.075 \mathrm{~m} \times 0.075 \mathrm{~m}$ pool filling with $6 \mathrm{~mL}$ heptane. The estimated heat release rates are $68 \mathrm{~kW}$ in intermediate scale and $2 \mathrm{~kW}$ in model scale. The extinction times for the pools were observed and found correlated well with predictions.

Table 4 A summary of the validation tests.

\begin{tabular}{|c|c|c|c|c|c|c|}
\hline Test no. & Scale & Pallet size & $N_{x}$ & $N_{y}$ & $N_{z}$ & $\begin{array}{c}\text { Total number of } \\
\text { pallets }\end{array}$ \\
\hline Test 1 & $\begin{array}{c}\text { Model scale } \\
1: 4\end{array}$ & $\begin{array}{c}1 / 4 \text { standard } \\
\text { pallet }\end{array}$ & 1 & 1 & 5 & 5 \\
\hline Test 2 & $\begin{array}{c}\text { Model scale } \\
1: 4\end{array}$ & $\begin{array}{c}1 / 4 \text { standard } \\
\text { pallet }\end{array}$ & 1 & 1 & 4 & 4 \\
\hline Test 3 & $\begin{array}{c}\text { Intermediate } \\
\text { scale } 1: 1\end{array}$ & $\begin{array}{c}1 / 2 \text { standard } \\
\text { pallet }\end{array}$ & 2 & 2 & 10 & 40 \\
\hline Test 4 & $\begin{array}{c}\text { Intermediate } \\
\text { scale } 1: 1\end{array}$ & $\begin{array}{c}1 / 2 \text { standard } \\
\text { pallet }\end{array}$ & 2 & 2 & 8 & 32 \\
\hline
\end{tabular}




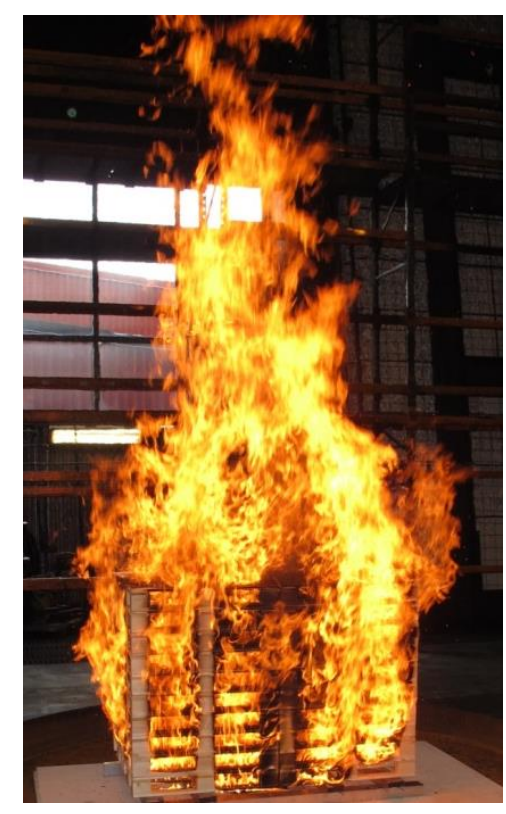

(a) Intermediate scale test 3

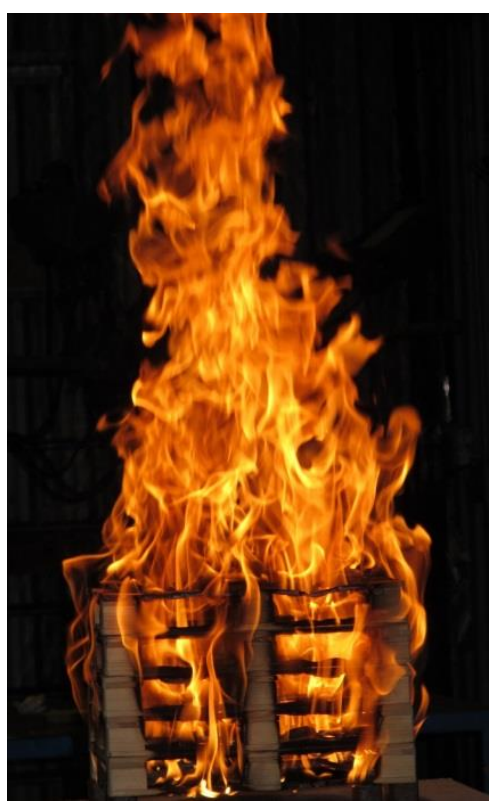

(b) Model scale Test 1

Figure 3 Test photos from tests(at intermediate scale time around 8 min ). 


\section{$5 \quad$ Results and discussion}

In the following, heat release rate curves obtained from the intermediate scale and model scale tests are compared. The heat release rates obtained from the model scale tests have been scaled up to the intermediate scale according to the correlation listed in Table 1 .

\subsection{Comparison of test results}

The heat release rates for the model scale test 1 and the intermediate scale test 3 are compared in Figure 4. Clearly, it shows in Figure 4 that the two heat release rate curves correlate very well during the whole burning period. The only exception is that in the intermediate scale test 3 , there exists a jump in the heat release rate at around $10 \mathrm{~min}$. The reason is that the wood pallet pile fell down at approximately $10 \mathrm{~min} 15$ seconds. This causes the total exposed fuel surface area increased suddenly resulting in an immediate increase in the heat release rate. This phenomenon has also been observed in other tests by the authors. In reality, commodities are mostly arranged in layers with steel frames, e.g. rack storage. If a steel frame was used in the tests, early collapse of the wood pallets can probably be avoided, and the sudden jump in Figure 4 would not appear.

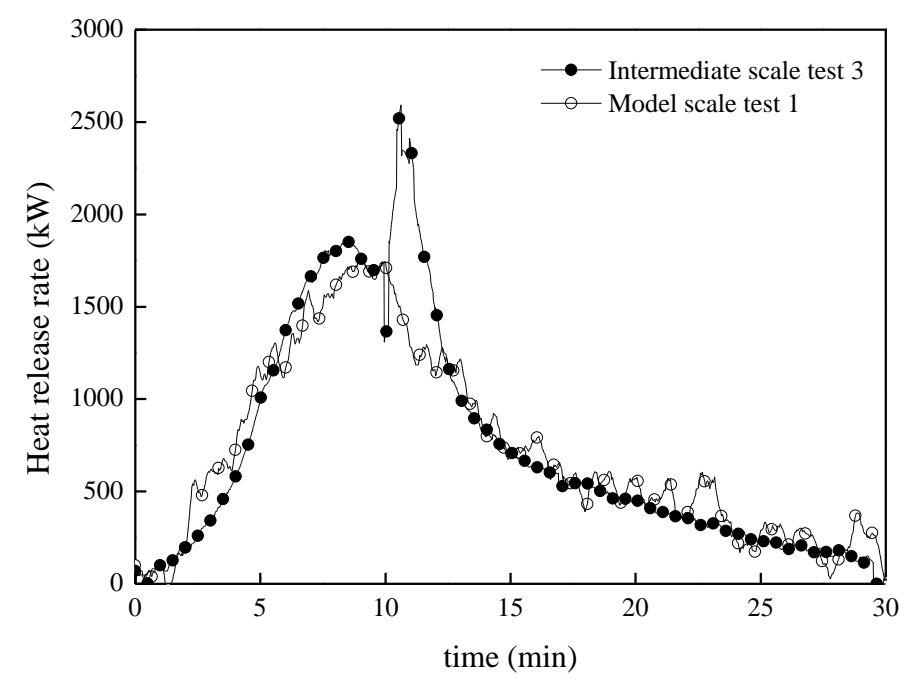

Figure 4 Comparison of heat release rates in model scale test 1(1:4) and intermediate scale test $3(1: 1)$.

A comparison of the heat release rates for the model scale test 2 and the intermediate scale test 4 is presented in Figure 5. Clearly, it can be seen from Figure 5 that the two heat release rate curves correlate well. One exception is that between $5 \mathrm{~min}$ and $10 \mathrm{~min}$ the heat release rates in model scale are slightly lower. It can also be observed that there is a small jump in the heat release rate at around $11 \mathrm{~min}$ in the intermediate scale test 4 . The same reason as given earlier can be used to explain this. After the intermediate scale test 3 , the wood pallets were packed more carefully to avoid early fall in the test, however, a small pile of wood pallets (approx. $25 \%$ of the total) still fell down at around 11 min and 30 seconds. As can be seen in Figure 5, this effect in this test is much less significant compared to test 3 .

In general, the comparisons of the time-resolved heat release rate curves from all the validation tests show very good agreement between the model scale and intermediate scale. That this correlation will also apply for full scale EUR pallets is likely. It is, however, not possible to do such tests as it requires very much fuel. This will be discussed further in Section 5.2. This good correlation between the model scale sized 
wood pallets and the intermediate sized pallets proves the reasonability and capability of the method proposed for scaling of time-resolved burning behaviors of wood pallet fires.

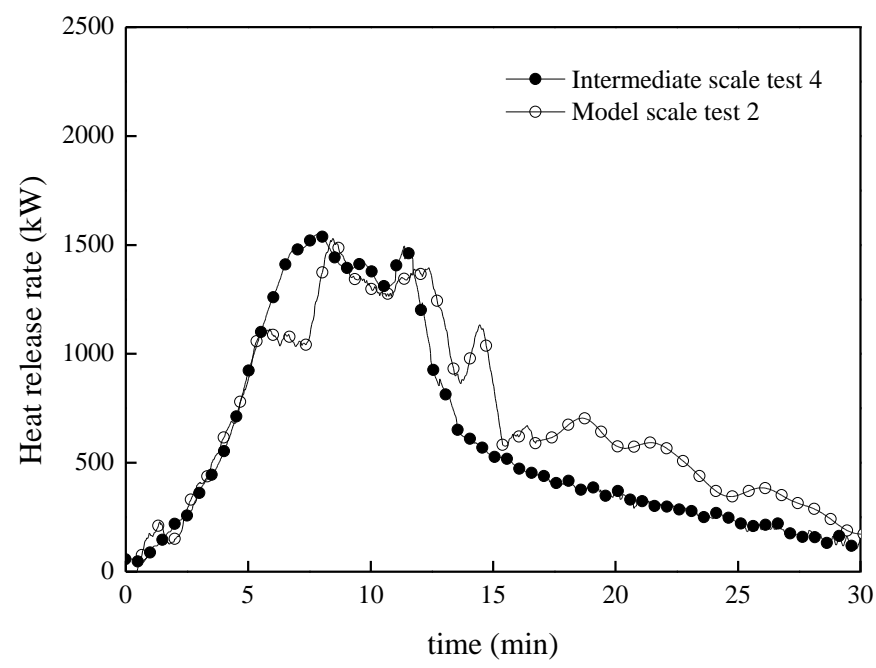

Figure $5 \quad$ Comparison of heat release rates in model scale test $2(1: 4)$ and intermediate scale test 4 (1:1).

\subsection{Maximum heat release rates}

Note that the burning rate for each wood pallet is assumed to be approximately a constant value and therefore about the same heat release rate per wood pallet is expected. The good correlation between intermediate scale and model scale found previously verifies this assumption. It can also be checked by use of test data for maximum heat release rate. Another reason for doing this is that the corresponding full scale wood pallet tests were not carried out due to the limitation of test scale. Therefore, some test data from literature can be used for comparison.

Arvidson [41] carried out one free burn fire test with 2 piles of standard wood pallets. Each pile had 10 EUR pallets and the spacing between piles was $15 \mathrm{~cm}$. The fire was initiated using a propane gas burner positioned on the floor, between the two piles of pallets. The flow of propane gas was shut off 2 min after ignition of the gas after which the fire was considered to be well established. The humidity of the wood pallets was in a range of $10 \%$ to $12 \%$, similar to those used in this study. The maximum heat release rate measured was $3800 \mathrm{kw}$ for 20 pallets when all pallets were involved. The average peak value for one pallet is therefore $190 \mathrm{~kW}$.

Test data for the maximum heat release rates are summarized in Table 5. The average heat release rate for one full scale pallet is $190 \mathrm{~kW}$, while the value is $48 \mathrm{~kW}$ for one $1 / 2$ wood pallet and $11.4 \mathrm{~kW}$ for one $1 / 4$ wood pallet. The corresponding full scale heat release rates per wood pallet (full scale pallet) are all in a range of $176 \mathrm{~kW}$ to $192 \mathrm{~kW}$. This strongly supports the assumption that the mass burning rates for wood pallets scale well and are approximately a constant value. This can be seen in Table 2 . It should be noted that the values given in Table 5 are suitable only for open fires or well ventilated fires. 
Table 5 Test data for maximum heat release rate in wood pallet fires.

\begin{tabular}{|l|c|c|c|c|}
\hline \multirow{2}{*}{ Test series } & Test no. & Total HRR & $\begin{array}{c}\text { HRR per } \\
\text { pallet }\end{array}$ & $\begin{array}{c}\text { Full scale HRR } \\
\text { per pallet }\end{array}$ \\
\hline & & $\mathrm{kW}$ & $\mathrm{kW}$ & $\mathrm{kW}$ \\
\hline Full scale [41] & & 3800 & 190 & 190 \\
\hline \multirow{2}{*}{$\begin{array}{l}\text { Intermediate } \\
\text { scale }\end{array}$} & 1 & 1850 & 46 & 185 \\
\hline \multirow{2}{*}{ Model scale } & 2 & 1537 & 48 & 192 \\
\cline { 2 - 5 } & 3 & 55 & 11.0 & 176 \\
\hline
\end{tabular}




\section{Summary}

A method for scaling time-resolved burning behaviours of wood pallet fires has been developed in this work.

The scaling method proposed shows that both the geometrical parameters for a single pallet and the number of pallets in each direction scale as $1 / 2$ power of the length scale. A summary of the scaling correlations is given in Table 2 .

In order to validate the scaling method, a series of tests was carried out in two different scales and the time-resolved heat release rates were obtained and compared. The results show that the scaling method proposed in this work works very well.

Test data for the maximum heat release rates obtained from tests in different scales were compared. The scaled-up heat release rates per wood pallet (full scale pallet) are all in a range of 176 to $192 \mathrm{~kW}$. This strongly supports the assumption on the mass burning rate for wood pallets and also indicates the full scale maximum heat release rate should scale well.

In reality, the scaling method proposed in this work is a general scaling method for pallet fires. Its use does not limit to a specific wood pallet. Instead, it can be applied to other similar types of fuels, e.g. more general wood pallets or plastic pallets, rather than only European wood pallets. The advantage of such a scaling is that individual parts can be scaled easily without any changes in details. 


\section{References}

1. Heskestad, G., Physical Modeling of Fire. Journal of Fire \& Flammability, 1975. 6: p. $253-273$.

2. Quintiere, J.G., Scaling Applications in Fire Research. Fire Safety Journal, 1989. 15: p. 3-29.

3. Ingason, H. In-Rack Fire Plumes. in Fire Safety Science - Proceedings of the Fifth International Symposium. 1997. Melbourne, Australia: IAFSS.

4. Perricone, J., M. Wang, and J. Quintiere, Scale Modeling of the Transient Thermal Response of Insulated Structural Frames Exposed to Fire. Fire Technology, 2007. 44(2): p. 113-136.

5. Li, Y.Z. and T. Hertzberg, Scaling of internal wall temperatures in enclosure fires, 2013, SP Technical Research Institute of Sweden: Borås, Sweden.

6. Heskestad, G., Scaling the interaction of water sprays and flames. Fire Safety Journal, 2002. 37: p. 535-548.

7. Heskestad, G., Extinction of gas and liquid pool fires with water spray. Fire Safety Journal, 2003. 38: p. 301-317.

8. Quintiere J.G., Su G.Y., and S. N., Physical scaling for water mist fire suppression - a design application. International Journal on Engineering Performance-Based Fire Codes, 2007. 9(2): p. 87-108.

9. Yu H.Z., Zhou X.Y., Ditch B.D. Experimental validation of Froude-modelingbased physical scaling of water mist cooling of enclosure fires. in 9th International Symposium on Fire Safety Science (Poster). 2008. Karlsruhe, Germany: IAFSS.

10. Yu H.Z. Physical scaling of water mist suppression of pool fires in enclosures. 2011. College Park, MD.

11. Bettis, R.J., S.F. Jagger, and Y. Wu, Interim Validation of Tunnel Fire Consequence Models: Summary of Phase 2 Tests, 1993, Health and Safety Executive: Buxton, Derbyshire, UK.

12. Oka, Y. and G.T. Atkinson, Control of Smoke Flow in Tunnel Fires. Fire Safety Journal, 1995. 25: p. 305-322.

13. Wu, Y. and M.Z.A. Bakar, Control of smoke flow in tunnel fires using longitudinal ventilation systems - a study of the critical velocity. Fire Safety Journal, 2000. 35: p. 363-390.

14. Ingason, H. and Y.Z. Li, Model scale tunnel fire tests with longitudinal ventilation. Fire Safety Journal, 2010. 45: p. 371-384.

15. Ingason, H. and Y.Z. Li, Model scale tunnel fire tests with point extraction ventilation. Journal of Fire Protection Engineering, 2011. 21(1): p. 5-36.

16. Ingason, H., Model Scale Railcar Fire Tests. Fire Safety Journal, 2007. 42(4): p. 271-282.

17. Vauquelin, O. and D. Telle, Definition and experimental evaluation of the smoke "confinement velocity" in tunnel fires. Fire Safety Journal, 2005. 40: p. 320-330.

18. Li, Y.Z., B. Lei, and H. Ingason, Study of critical velocity and backlayering length in longitudinally ventilated tunnel fires. Fire Safety Journal, 2010. 45: p. $361-370$.

19. Li, Y.Z., B. Lei, and H. Ingason, The maximum temperature of buoyancy-driven smoke flow beneath the ceiling in tunnel fires. Fire Safety Journal, 2011. 46(4): p. 204-210.

20. Li, Y.Z. and H. Ingason, The maximum ceiling gas temperature in a large tunnel fire. Fire Safety Journal, 2012. 48: p. 38-48.

21. Li, Y.Z., B. Lei, and H. Ingason, Theoretical and experimental study of critical velocity for smoke control in a tunnel cross-passage. Fire Technology, 2013. 49: p. 435-449. 
22. Li, Y.Z., B. Lei, and H. Ingason, Scale modeling and numerical simulation of smoke control for rescue stations in long railway tunnels. Journal of Fire Protection Engineering, 2012. 22(2): p. 101-131.

23. Lönnermark, A., J. Lindström, and Y.Z. Li, Model-scale metro car fire tests, SP Report 2011:33, SP Technical research Institute of Sweden, 2011, Borås, Sweden.

24. Lönnermark, A., Lindström, J., Li, Y.Z., Alexander C., Mia K., and H. Ingason, Full-scale fire tests with a commuter train in a tunnel, SP Report 2012:05, SP Technical Research Institute of Sweden, 2012, Borås, Sweden.

25. Ingason, H., Model scale tunnel tests with water spray. Fire Safety Journal, 2008. 43(7): p. 512-528.

26. Croce, P.A., Modeling of vented enclosure fires part $i$ : quasi-steady wood-crib source fires, FMRC J.I. 7A0R5.GU, Factory Mutual, 1978.

27. Li, Y.Z., et al., Model scale tunnel fire tests with water-based fire suppression systems, SP Report 2014:02, SP Technical Research Institute of Sweden, 2014, Borås, Sweden.

28. Gross, D., Experiments on the Burning of Cross Piles of Wood. Journal of Research of the National Bureau of Standards-C. Engineering and Instrumentation, 1962. Vol. 66C(2): p. 99-105.

29. Block, J.A., A theoretical and experimental study of nonpropagating free-burning fires. Thirteenth Symposium (International) on Combustion, The Combustion Institute, 1970: p. p. 971-978.

30. Heskestad, G. Modeling of Enclosure Fires. in Proceedings of the Fourteenth Symposium (International) on Combustion. 1972. The Pennsylvania State University, USA: The Combustion Institute.

31. Croce, P.A., Modeling of Vented Enclosure Fires Part I. Quasi-steady Wood-crib Source Fire, Factory Mutual Research Corporation, 1978, Norwood, Massachusetts, USA.

32. Croce, P.A. and Y. Xin, Scale modeling of quasi-steady wood crib fires in enclosures. Fire Safety Journal, 2005. Vol. 40: p. 245-266.

33. Ingason, H., A. Lönnermark, and Y.Z. Li, Runehamar Tunnel Fire Tests, SP Report 2011:55, SP Technical Research Institute of Sweden, 2011, Borås, Sweden.

34. Ingason, H., Appel G., Li Y.Z., Lundström U. and C. Becker. Large scale fire tests with a Fixed Fire Fighting System (FFFS). in ISTSS 6th International Symposium on Tunnel Safety and Security. 2014. Marseille.

35. Mawhinney, J., Fixed Fire Protection Systems in Tunnels: Issues and Directions. Fire Technology, 2011.

36. Heskestad, G. Flame Height of Fuel Arrays with Combustion in Depth. in Fire Safety Science - Proceedings of the Fifth International Symposium. 1997. Melbourne, Australia: IAFSS.

37. Li, Y.Z. and H. Ingason. The fire growth rate in a ventilated tunnel fire. in 10th International Symposium on Fire Safety Science (IAFSS). 2011. Maryland, USA, pp. 347-358.

38. Li, Y.Z., H. Ingason, and A. Lönnermark. Fire development in different scales of train carriages. in 11th International Symposium on Fire Safety Science. 2014. New Zealand.

39. Li, Y.Z., H. Ingason, and A. Lönnermark, Correlations in different scales of metro carriage fire tests, SP Report 2013:13 SP Technical Research Institute of Sweden, 2013, Borås, Sweden.

40. Ingason, H., Y.Z. Li, and A. Lönnermark, Tunnel Fire Dynamics, 2015, New York: Springer.

41. Arvidson, M., Idle pallet storage - free-burn fire tests, SP Technical Research Institute of Sweden, 2006, Borås, Sweden. 


\section{SP Technical Research Institute of Sweden}

Our work is concentrated on innovation and the development of value-adding technology. Using Sweden's most extensive and advanced resources for technical evaluation, measurement technology, research and development, we make an important contribution to the competitiveness and sustainable development of industry. Research is carried out in close conjunction with universities and institutes of technology, to the benefit of a customer base of about 9000 organisations, ranging from start-up companies developing new technologies or new ideas to international groups.

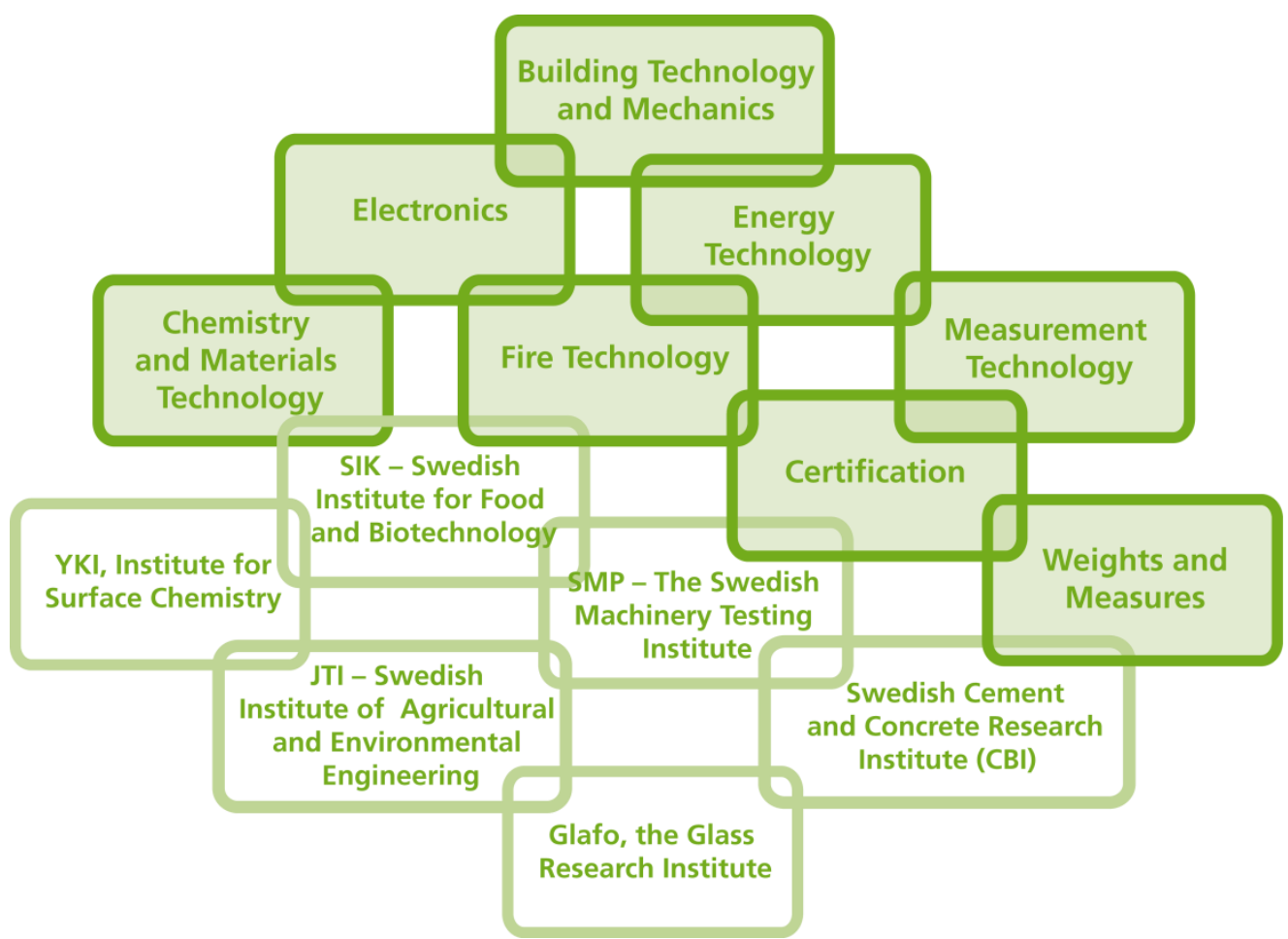

SP Technical Research Institute of Sweden Box 857, SE-501 15 BORÅS, SWEDEN

Telephone: +461051650 00, Telefax: +46 33135502

E-mail: info@sp.se, Internet: www.sp.se

www.sp.se
Fire Research

SP Report 2014:57

ISBN 978-91-88001-01-6

ISSN 0284-5172

More information about publications published by SP: www.sp.se/publ 